\title{
On Antecedents of Functional Elaboration of HRM in Small Firms
}

\author{
James M. Wilkerson \\ The Pennsylvania State University
}

\author{
Anson Seers \\ Virginia Commonwealth University \\ Sharon G. Johnson \\ Charleston Southern University
}

\begin{abstract}
This work further develops the foundation for a functional elaboration theory of human resource management (HRM) in small firms (Wilkerson \& Seers, 2019) by detailing some antecedents of HRM's qualitative and quantitative elaboration in the small firm. Whereas theoretical development in this area to date has focused on functional elaboration and associated fit or misfit of HRM to relevant contingencies, adequate explanation of antecedents has been lacking. We present propositions regarding several entrepreneurial and organizational predictors of, as well as relevant interactive effects on, HRM's functional elaboration in small firms.
\end{abstract}

Keywords: HRM functional elaboration, small-firm human resource management, entrepreneurship

\section{INTRODUCTION}

Functional elaboration of the human resource management (HRM) function in small firms describes the internal structuration process (Giddens, 1984; Mintzberg, 1980), typically initiated by the small firm's founder(s), whereby HRM is established, quantitatively elaborated (expanded more broadly to capture HRM subfunctions), and qualitatively elaborated (deepened and made more sophisticated, complex, and tied to firm performance; Wilkerson \& Bassani, in press; Wilkerson \& Seers, 2019). The elaborative process entails "a series of decisions, resource allocations, task assignments, policy making, authorizations, patterned actions, related communications, and the like, often all done or at least initiated by the owner-manager" (Wilkerson \& Seers, 2019, p. 163). As Wilkerson and Bassani (in press) clarified, a business function in a small firm "may display more or less of the state of functional elaboration, but the functional elaboration process that establishes that state is what entrepreneurs...first and foremost must do and manage" (cf. Wilkerson \& Seers, 2019, p. 163).

Wilkerson and Seers (2019) detailed this process at length and explained how insufficient, careless functional elaboration of HRM may result in the function's harmful underfit relative to contingencies the small firm faces. According to the theory of asymmetric effects of misfit, such underfit, in turn, threatens the small firm's goal achievement and performance (Klaas \& Donaldson, 2009; Klaas, Lauridsen, \& Håkonsson, 2006). More recently, Wilkerson and Bassani (in press) applied functional elaboration 
concepts to the management accounting function in small firms. This work included consideration not only of low functional elaboration and associated underfit, but also of excessive, misguided functional elaboration and associated overfit of management accounting systems and practices relative to contingencies. While not threatening the small firm's goal achievement as underfit does, functional overfit does pose costly inefficiency (Klaas \& Donaldson, 2009; Klaas et al., 2006).

\section{FIGURE 1 \\ INFLUENCES ON AND OF HRM'S LOW QUALITATIVE FUNCTIONAL ELABORATION IN SMALL FIRMS}

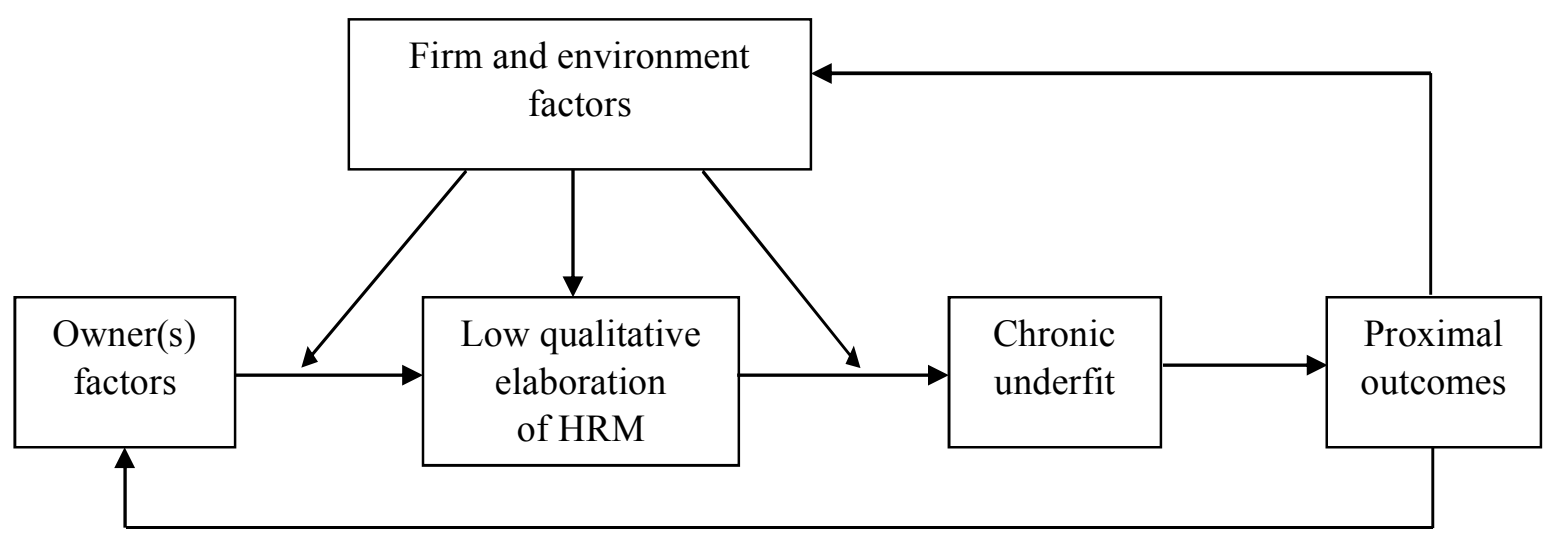

(with permission from Wilkerson \& Seers, 2019, p. 170)

Low qualitative functional elaboration of HRM in the small firm and related chronic underfit were the mediating factors in a basic process model Wilkerson and Seers (2019) provided (see Figure 1) and which Wilkerson and Bassani (in press) adapted to the small firm's management accounting function. In discussing the process model beyond its two central constructs, both works mentioned proximal, negative firm outcomes that would logically occur when functional underfit exists (e.g., poor person-job fit, adverse workplace injury rates, weak training transfer, adverse unemployment claim outcomes). Also, Wilkerson and Seers did mention environmental factors of governmental regulation, economic downturn, and untapped market opportunities that could affect functional elaboration directly and, more importantly, moderate its link to underfit. Neither Wilkerson and Seers (2019) nor Wilkerson and Bassani (in press) adequately explained the organizational and entrepreneur/owner-manager factors that predict low functional elaboration in the small firm beyond listing some of them, however.

We focus herein on those organizational and entrepreneur/owner-manager factors lest functional elaboration theory be underspecified and fail to incorporate variables that may cause, and certainly set boundary conditions for, the way functional elaboration, misfit, and proximal outcomes interrelate in small firms. No theory is perfect, and a process model alone does not constitute theory (Suddaby, 2010; Sutton \& Staw, 1995; Whetten, 1989), but we can improve on functional elaboration theory by addressing more of the left side of the Wilkerson and Seers (2019) process model. To that end, Figure 2 lists the antecedents discussed in the following sections and suggests that some organizational and entrepreneur/owner-manager antecedents may also interact in influencing functional elaboration of HRM in small firms. 
FIGURE 2

FACTORS INFLUENCING FUNCTIONAL ELABORATION OF HRM IN SMALL FIRMS

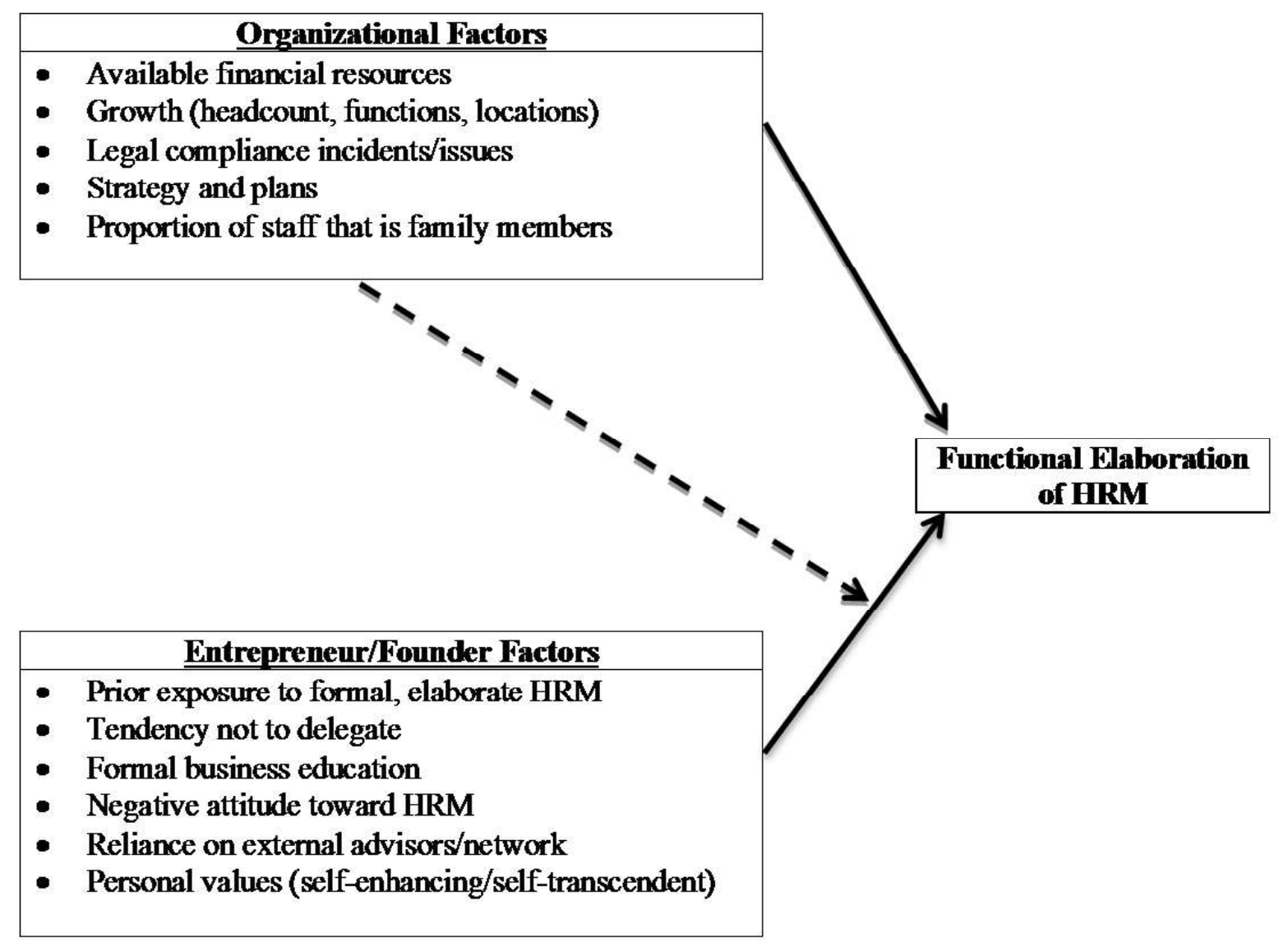

\section{ENTREPRENEUR/OWNER-MANAGER ANTECEDENTS}

\section{Prior Exposure to Formal, Elaborate HRM}

Entrepreneurs' prior work experience may affect their business decision making, especially at the small firm's startup (Shepherd, Williams, \& Patzelt, 2015). Entrepreneurs with prior exposure to more elaborated HRM, typically gained in larger firms during prior employment, may be more likely to elaborate HRM in their own small firms (Bacon, Ackers, Storey, \& Coates, 1996; Davila, 2005; Keating \& Olivares, 2007; Klaas \& Klimchak, 2006). Even if the entrepreneur did not formerly work in an HR department or particularly like how HRM functioned in prior settings, the prior experiences with HRM activities would tend to inform the entrepreneur's schema of what HRM is and looks like in a workplace, and would tend to teach the entrepreneur what HRM problems are acute enough to require attention and related elaboration (Greer, Carr, \& Hipp, 2016; Harris, 1994; Tocher \& Rutherford, 2009). Tocher and Rutherford found that more experience was associated with small-firm managers' likelihood of perceiving HRM problems as acute, presumably because the prior experience sensitized them to both the symptoms and the threat of HRM problems. As explained above, this initial perception of an HRM problem serves to direct the owner-manager's attention toward whatever decisions, resource allocations, policies, and so forth (i.e., functional elaboration) are needed to address the HRM problem.

Proposition 1: The entrepreneur's prior exposure to HRM, especially well-elaborated HRM, through earlier work experience is positively associated with HRM's elaboration in the entrepreneur's small firm. 


\section{Tendency Not to Delegate}

Research findings on the entrepreneur's delegation tendency implicate HRM's elaboration (Marlow, Taylor, \& Thompson, 2010; Mazzarol, 2003). Many sources comment on how small firms' ownermanagers can be reluctant to relinquish some control and delegate decisions and tasks to subordinate employees (e.g., Brettel, Engelen, \& Voll, 2010; Davidsson, 1989; Fuller-Love, 2006; Oakey, 2003), and some have cited this tendency specifically with respect to HRM in small firms (e.g., Barrett \& Mayson, 2007; Koch \& de Kok, 1999; Marlow, 2006; Mayson \& Barrett, 2006a, 2006b). Entrepreneurs who insist on handling their small firms' HRM themselves may quantitatively elaborate HRM to at least a superficial degree but are not as likely to qualitatively elaborate the function unless they happen to have particular expertise in the HRM activities needing deeper elaboration. Even if the entrepreneurs have the expertise, they may not have the time to elaborate HRM very well, given all the other demands of starting up and developing a small firm (Mayson \& Barrett, 2006b). In the worst case, the failure to delegate becomes self-reinforcing when owner-managers refuse to hire someone to handle HRM matters due to being unwilling to delegate HRM, and then insist that their reluctance to delegate is justified because the firm has no one else on staff qualified to take over HRM duties. Extended to other business functions and activities, this dynamic also has the effect of stunting the small firm's growth (Davidsson, 1989), which in turn lessens the entrepreneur's felt need to delegate HRM for the sake of elaborating it since employee issues are relatively static when the firm is not growing.

Proposition 2: Qualitative elaboration of HRM in small firms is less likely when owner-managers are predisposed not to delegate HRM-related tasks and decisions to subordinate employees.

\section{Formal Business Education}

Sometimes entrepreneurs do not elaborate HRM because they have never been formally educated as to what HRM is and how it can aid firm functioning (Fuller-Love, 2006; Koch \& de Kok, 1999). Such entrepreneurs may wend their way to elaborating HRM as a function of experiences gained, but formal business education should make entrepreneurs at least more aware of the need to establish certain HRM practices and policies, if only for the sake of startup staffing and legal compliance. Typical college business degree programs expose students to HRM principles, and even introductory entrepreneurship and small-business management courses have content and use textbooks that pay explicit attention to staffing, compensation, training, and job analysis, for instance (Neck \& Greene, 2011; Scarborough, 2011). Besides imparting basic HRM knowledge, the typical business school experience can equip entrepreneurs with reference sources (textbooks and professors) that entrepreneurs with no formal business education may be less likely to have.

Davidsson (1989) reasoned that higher education can improve entrepreneurs' ability to detect growth opportunities, and Tocher and Rutherford (2009) found that small-firm owner-managers with college degrees were more likely than lesser-educated owner-managers to perceive acute HRM problems. As we described above, detecting such market opportunities and HRM problems leads to actions entrepreneurs take to adapt operations and their firms' business models, including functionally elaborating HRM as needed.

Proposition 3: Entrepreneurs who have formal business education are more likely to elaborate HRM in their small firms.

\section{Negative Attitude Toward HRM}

Many entrepreneurs have a negative attitude specifically toward HRM, primarily because they associate HRM with bureaucracy and administrative "red tape," seeing the business function as a stifling curb on their and their firm's flexibility and innovativeness, a condition of which many researchers have also warned (Baron, Burton, \& Hannan, 1996; Bartram, 2005; Cardon \& Stevens, 2004; Mintzberg, 1980). Some entrepreneurs develop this negative attitude through direct experience with cumbersome HRM practices and formalization (Cardy \& Miller, 2006), but some may acquire the negative attitude 
simply through social learning and stereotypes. Modern cartoon strips and television situation-comedy series have profitably mocked HRM and, in the process, convinced impressionable entrepreneurs with little or no direct HRM knowledge or experience that HRM is something to avoid or deemphasize in their business pursuits. Applying the well-known tripartite concept of attitude structure (Rosenberg \& Hovland, 1960), this condition implies a negative feeling (affect) toward the HRM business function, a tendency to avoid (behavioral intent) HRM, and a belief or conviction (cognition) that HRM somehow harms or impedes the small business. Attitudes influence intentional behaviors (Ajzen, 1991), especially when the actor has the kind of strong behavioral control that small firms' owner-managers tend to have; thus, entrepreneurs with negative attitudes toward HRM are more likely to defer HRM's elaboration and formalization as long as they possibly can.

Proposition 4: The more negative the entrepreneur's attitude toward HRM is, the less the small firm's HRM will be elaborated.

\section{Reliance on External Advisors/Network}

Some entrepreneurs rely on their network of advisors (e.g., attorneys, bankers, accountants, consultants), vendors, clients, competitors, and small-business peers for insights on a host of market opportunities, startup problems, survival tips, sales and marketing advice, and so on (Bacon \& Hoque, 2005; Baron, 2006; Bird, 1988; Hoang \& Antoncic, 2003; Jay \& Schaper, 2003; Pollack, Rutherford, Seers, Coy, \& Hanson, 2016). Network effects on small firms' financial outcomes are fairly well researched, but empirical research relating such networks specifically to HRM's elaboration in small firms (e.g., Harris, 2000) is scant. Perhaps the next closest thing is extant research on network effects in small firms' recruiting efforts (e.g., Leung, Zhang, Wong, \& Foo, 2006) and small firms' use of professional HRM service providers and outsources (e.g., Klaas, McClendon, \& Gainey, 2000). Nonetheless, an entrepreneur's network contacts can offset some lack of HRM experience and education the entrepreneur may have, especially if the network contacts are large in number, which permits receiving relatively more HRM advice, and of relatively high quality, which permits potentially deeper information, more patience in explaining things, and so forth due to the enhanced relationships residing in high-quality network contacts (Pollack et al., 2016). Network contacts can share their own experiences with HRM; provide exemplars of documents they have used in formalizing HRM; refer the entrepreneur to other advisors, outsources, informational websites; and so forth. This information gives entrepreneurs at least general guidance on decisions, resource allocations, and policy content related to elaborating HRM in their small firms.

Proposition 5: HRM's elaboration in the small firm is positively associated with the extent to which the owner-manager relies on external network advice.

\section{Personal Values}

Entrepreneurs' personal values and related motives are even more fundamental to their business behavior than their specific attitudes (Kotey \& Meredith, 1997). These values are deeply held, learned beliefs and preferences for certain end states and behaviors, and accordingly influence behavioral choices across almost all situations and circumstances (Schwartz, 1992). Small-firm owner-managers' personal values and goals shape their business goals, plans, and strategies. Since business functions operate in service of the owner-managers' business goals, plans, and strategies (Kotey \& Meredith, 1997), ownermanagers' personal values can influence whether or not they elaborate HRM.

Two higher-order value types that may be relevant to how likely entrepreneurs are to elaborate HRM in their small firms are self-transcendence, which is marked by motivations to promote the welfare of others and nature, and self-enhancement, which is marked by motivations to pursue personal interests (Schwartz, 1992). Gorgievski, Ascalon, and Stephan (2011) found that small-business owners' valuesbased business success criteria included a business-oriented dimension that reflected profitability versus contributing back to society. Self-enhancing value orientations were associated with the profitability 
criterion, whereas self-transcendent value orientations guided the criterion of giving back to society. This latter value orientation relates to entrepreneurs' values and beliefs that Bird (1988) held shape some entrepreneurs' focus and intentionality in pursuing noneconomic market opportunities and business goals.

In a similar vein, Wach, Stephan, and Gorgievski (2016) found that entrepreneurs have multifaceted definitions of entrepreneurial success, which the researchers measured in terms of multi-item scaled degree of importance to the entrepreneur. The success facets included firm performance, workplace relationships, personal fulfillment, community impact (most related to the self-transcendent value orientation in Gorgievski et al., 2011), and personal financial rewards (most related to the self-enhancing value orientation in Gorgievski et al., 2011). The community impact and workplace relationships

dimensions are most related to self-transcendent value orientations in that they tapped importance of things like the firm's social contribution, social responsibility for employees, and employee satisfaction. The personal financial rewards and, to a lesser extent, personal fulfillment dimensions are more related to self-enhancing value orientations in that they tapped importance of things like personal financial security and income growth, personal decision-making autonomy, and personal work flexibility.

Owner-managers hold dominant sway in decisions, resource allocations, task assignments, policy making, and authorizations that constitute elaboration of HRM in small firms. HRM elaboration entails expenses that can cut into profits otherwise payable to the entrepreneur. It also potentially involves binding rules and policies that employees and other stakeholders expect the entrepreneur to follow and to enforce. The self-enhancing entrepreneur may oppose these conditions. On the other hand, qualitative elaboration of HRM (particularly in compensation, training, and employee relations practices) can go to enhancing employee welfare, which is something the self-transcendent entrepreneur may particularly appreciate. Thus, we expect that the entrepreneur's dominant value orientation can influence elaboration of HRM in the small firm.

Proposition 6: Entrepreneurs with self-enhancing personal value orientations are less likely to elaborate HRM in their small firms, whereas entrepreneurs with self-transcendent personal value orientations are more likely to do so.

\section{ORGANIZATIONAL ANTECEDENTS}

\section{Available Financial Resources}

Many sources note the expense of adopting HRM practices (e.g., Litz \& Stewart, 2000; López, Neves, \& Cunha, 2019; Patel \& Cardon, 2010; Sels et al., 2006; Tocher \& Rutherford, 2009; Welsh \& White, 1981), so the small firm's financial resources predict functional elaboration of HRM. Especially during and immediately following startup, far more cash is typically leaving the small firm than is coming in, motivating the entrepreneur to keep expenses in check. Elaborating HRM costs money and takes time, however, even at rudimentary levels and especially at qualitatively elaborated levels (Patel \& Cardon, 2010; Way, 2002); thus, small firms with little organizational slack will typically find it difficult to invest in HRM practices (Tocher \& Rutherford, 2009). On the other hand, at least some HRM elaboration may be necessary for startup firms to achieve stable operations and a degree of resulting financial stability (Klaas \& Klimchak, 2006; López et al., 2019). Qualitatively elaborating staffing, training, and compensation practices beyond the basic practices established during initial quantitative elaboration can be especially expensive. For instance, small firms' hiring volume is much lower than that of large firms, such that the small firms cannot achieve economies of scale from enhanced, more expensive recruiting and selection techniques (Barber, 2006). The same is true for training in small firms in that enhancing training for application to relatively few employees is inefficient (Fuller-Love, 2006; Litz \& Stewart, 2000).

Proposition 7: The small firm's level of available financial resources is positively associated with HRM's elaboration. 


\section{Growth}

Structuration principles suggest that headcount growth, as well as growth across business functions and physical locations, will require structural changes such as HRM elaboration in order to achieve coordination, control, and consistency of formalized behavior across employees and work units (Katz \& Kahn, 1978; López et al., 2019; McKelvie \& Wiklund, 2010). Whereas headcount growth certainly implicates mostly quantitative elaboration, growth in work locations and business functions probably affects qualitative elaboration more. Growing small firms are more likely to have staff at multiple locations than are non-growing small firms (Mayson \& Barrett, 2006a). Especially if across state or province lines or national borders, different work locations will be associated with, for instance, different recruitment advertising sources, different features of local labor pools, possibly different prevailing wage rates, different employment law enforcement environments, and so forth. This added complexity relates to qualitative elaboration of HRM (Bacon \& Hoque, 2005; Wright \& Gardner, 2003).

To the extent different business functions require different employee skills and professional statuses and present different work designs, the small firm's owner-manager will find existing staffing, training, and pay practices require modification as the firm grows (Bacon \& Hoque, 2005; Baron et al., 1996). Consider, for instance, how a small service or manufacturing firm's HRM often is at startup, with only a small cadre of owner(s), skilled designers, and other professional personnel on board performing a few critical business functions, and then how the HRM must change a short time later to accommodate semiskilled operative labor, expanded clerical labor, and the like, now performing production and extended support functions that did not exist in the firm before. Our point is that headcount growth is not the only kind of growth associated with HRM's elaboration, and small firms' owner-managers must consider what happens in terms of HRM if and when the firm begins adding business functions soon after startup and, later on, establishing staffed operations in additional physical locations (Katz \& Kahn, 1978).

Research has well established that small firms' HRM is less elaborated than larger firms' HRM, which suggests that elaboration of HRM in the small firm is particularly likely when growth is underway (e.g., Bartram, 2005; Cardon \& Stevens, 2004; Hornsby \& Kuratko, 2003; Kotey \& Sheridan, 2004; Kotey \& Slade, 2005; López et al., 2019; Marlow et al., 2010). This is also true when looking just within the small-firm category. Small, growing firms display more HRM elaboration than small, non-growing firms do (Barrett \& Mayson, 2007; Mayson \& Barrett, 2006b; cf. Marlow, 2006). Some HRM elaboration aids growth, and growth also triggers certain HRM elaboration as prior HRM practices and systems meet their capacity limits (Goswami, McMahan, \& Wright, 2006; Klaas \& Klimchak, 2006).

Proposition 8: The small firm's growth (in headcount, staffed locations, and business functions) is positively associated with HRM's elaboration.

\section{Legal Compliance Incidents/Issues}

Some elaboration of HRM in small firms happens as a result of legal regulations and employment laws (Bartram, 2005; Marlow, 2002). This does not suggest that all entrepreneurs are versed in the various employment laws affecting their small firms. Many are not (Barrett \& Mayson, 2007; Blackburn \& Hart, 2002), and some who are aware may simply choose not to comply with those laws (Bacon \& Hoque, 2005; Marlow, 2002). When regulators detect legal compliance violations or adverse actions involving employment laws occur, however, even resistant entrepreneurs may be begrudgingly motivated to elaborate HRM to the extent needed to correct the problem and avoid costly consequences of noncompliance in the future (Crain \& Crain, 2010; Patel \& Cardon, 2010). For instance, a small firm may lack an official disciplinary action policy and related formalization by way of a standard form to record disciplinary actions. This may change later, however, when the small firm loses its first contested unemployment insurance claim by some ex-employee whom the owner-manager repeatedly warned and then justifiably dismissed, and the outcome is at least partly due to a lack of any documented records of the employee having been fairly warned. 
Proposition 9: Employment law-related compliance incidents or issues are positively associated with HRM's elaboration in small firms.

\section{Strategy and Plans}

Many sources suggest that small firms' owner-managers do little strategic planning; indeed, even their very short-term, tactical business plans may not be particularly detailed or deep (Chadwick, Way, Kerr, \& Thacker, 2013; Perry, 2001). In Katz and Kahn's (1978) terms, small firms appear to coordinate reactively through feedback much more than they coordinate proactively through planning (cf. Tocher \& Rutherford, 2009). We also know that small firms' owner-managers do not place the same premium on HRM strategy, in particular, as researchers typically do (Heneman, Tansky, \& Camp, 2000; Marlow, 2006; Wiesner \& McDonald, 2001). Indeed, many small-firm owner-managers simply do not perceive HRM as strategic, and they value HRM professionals more for administrative and tactical activities than for planning and strategy formulation (Nankervis, Compton, \& Savery, 2002). To the extent the empirical description and academic prescription of the matter do not match, the robust research on HRM strategy in small firms may reflect researchers' preferences and scholarly training more than entrepreneurs' actual interests.

In any case, scholars conditioned by the strategic human resource management (SHRM) body of research have often attempted to relate the strategies, HRM practice configurations, and so forth reflective of SHRM to small-business HRM (e.g., Goswami et al., 2006; Mayson \& Barrett, 2006b). Certainly, theories often cited in SHRM research may also apply to elaboration of HRM in small firms in various ways. For instance, properly elaborating HRM may be seen as a process contributing to the relative inimitability of a small firm's personnel under the resource-based view (RBV) of the firm (Barney, 1991; Mayson \& Barrett, 2006b; Tocher \& Rutherford, 2009), and RBV-based theory may even predict whether HRM's elaboration is more proactively planned (Wright \& McMahan, 1992). Structural contingency theory (Burns \& Stalker, 1961), on the other hand, may predict more reactive, ad hoc elaboration of HRM in small firms.

Hannan, Burton, and Baron (1996) reported that founders' business strategies were associated with the HRM models used in young firms, although this alignment did tend to change as things like firm growth and top management changes occurred. In terms of strategic archetypes, Hayton (2003) reasoned that small firms pursuing cost leadership strategies would be less likely to incur HRM costs. This suggests that qualitative elaboration, in particular, may be negatively associated with the cost leadership strategy since qualitative elaboration of HRM is often done with regard to more discretionary HRM practices and represents potential expenses and professionalization beyond initial quantitative elaboration of more traditional HRM practices. On the other hand, small firms pursuing differentiation strategies may experience more pressure to elaborate HRM qualitatively in ways that support frequent changes in product lines, enhanced market monitoring, and other features required under the strategy.

Absent any clearly defined strategy, the question may be whether HRM's elaboration in a small firm is at least triggered by rudimentary planning the entrepreneur does. For instance, even entrepreneurs quite unfamiliar with HRM at startup would likely see the need to establish a basic hiring practice and perhaps on-the-job training for the small firm's first several hires. Beyond this quantitative elaboration, though, other HRM elaboration may occur reactively in response to unanticipated, unplanned issues and events, especially given firm growth. For instance, small firms' owner-managers may implement discipline policies only after experiencing some kind of employee performance issue or general employee relations problem. Employee health and safety practices may be very basic until the first workplace injury occurs, spurring the owner-manager to articulate some more detailed, explicit safety rules and to establish some preventative safety practices. Knowing which HRM practices and activities lend themselves more to proactively planned elaboration versus unplanned, reactive elaboration would be useful information for entrepreneurs and scholars alike.

Proposition 10: Qualitative elaboration of HRM in small firms is more associated with a differentiationfocused competitive strategy and less associated with a cost-leadership competitive strategy. 


\section{Proportion of Staff Comprised of Family Members}

Research on family-owned small firms generally suggests that family-based firm management is associated with less qualitatively elaborated HRM (Barnett \& Kellermanns, 2006; De Kok, Uhlaner, \& Thurik, 2006). Relative to other employees, family members usually present fewer of the demands and issues that can spur HRM's elaboration. For instance, the owner-manager's daughter, nephew, grandchild, or son-in-law is less likely to threaten the small firm with a legal action involving some employment matter, and the owner-manager need not observe many typical recruiting and selection practices to hire these relatives (De Kok et al., 2006). Also, family members may be more sympathetic and deferential to the founder's desires or may be more likely to have a financial stake in the firm, and thus not clamor for expensive HRM enhancements the way non-family members might (Neckebrouck, Schulze, \& Zellweger, 2018). There is some risk of work roles getting blurred with family roles in small firms employing family members (Taylor, 2006), and certainly there is no guarantee that family members the owner-manager feels compelled to hire are particularly qualified or competent (Chrisman, Memili, \& Misra, 2014; Taylor, 2006). On balance, though, family members present relatively fewer HRM demands as employees, and family members are more positive about the firm (Vardaman, Allen, \& Rogers, 2018).

Bacon et al. (1996) found that family-owned small firms were less likely to change or to update management practices, including performance appraisal and management development practices. Bacon and Hoque (2005) hypothesized family-owned or family-run small- and medium-sized firms would have fewer HRM practices (i.e., less quantitative elaboration of HRM), but did not find empirical evidence supporting this hypothesis. They did not, however, control for firm size or the relative proportion of firm staff that was comprised of family members. We would expect the strongest effect of family involvement to occur when the proportion of firm staff comprised of the owner-manager's family members is bigger and, therefore, potentially more restrictive with regard to HRM elaboration (Barnett \& Kellermanns, 2006).

Proposition 11: The higher the proportion of the small firm's staff members who are the entrepreneur's relatives, the less HRM will be elaborated.

\section{MODERATING INTERACTIONS}

Although not empirically tested often, some of these organizational factors may moderate the link between owner-manager factors and the small firm's HRM elaboration. The small firm's available financial resources may especially qualify owner-managers' personal gain values (i.e., self-enhancing personal value orientations), and the small firm's growth may especially qualify owner-managers' delegation tendencies and negative attitudes toward HRM. Regarding the former, we know that more available financial resources are associated with more elaboration of HRM (Tocher \& Rutherford, 2009). This should be especially so for entrepreneurs who value personal gain relatively less. Entrepreneurs who strongly value personal gain would show relatively modest increases in elaborating HRM as firm financial condition improves, whereas better firm financial condition would free entrepreneurs less motivated by personal gain to elaborate both standard and discretionary HRM practices (Hayton 2003), many of which would have been deferred when the firm's finances were tighter.

Proposition 12: The relationship between the small firm's financial resource availability and HRM's elaboration will be more positive for entrepreneurs who have relatively low motivation for personal gain.

We also know that firm growth is associated with more elaboration of HRM (Kotey \& Sheridan, 2004). This should be especially so for entrepreneurs who are relatively resistant to delegating or who have relatively more negative attitudes toward HRM. We expect this because such entrepreneurs would likely not elaborate HRM much, if any, when the small firm is not growing, but growth in headcount, locations, product/service lines, and so forth will compel those entrepreneurs to elaborate HRM at least enough to address pressures and imperatives from the growth. Entrepreneurs who delegate more readily 
and who have relatively less negative attitudes toward HRM should always be somewhat more likely to elaborate their small firms' HRM; thus, the elaborative range from low growth to high growth conditions is less dramatic for such entrepreneurs.

Proposition 13a: The relationship between the small firm's growth and HRM's elaboration will be more positive for entrepreneurs who are relatively more resistant to delegating.

Proposition 13b: The relationship between the small firm's growth and HRM's elaboration will be more positive for entrepreneurs who have relatively more negative attitudes toward HRM.

\section{IMPLICATIONS FOR PRACTICE AND ENTREPRENEURSHIP EDUCATION}

Identifying antecedents of HRM's functional elaboration helps to fill in some blanks about how and why the small firm's HRM practices, routines, and form come to be. Whether or not the small firm's HRM function enhances firm performance is, according to functional elaboration theory, a matter of the function's fit with performance-relevant contingencies, and this fit flows directly from how the small firm, mostly by way of owner-manager action, elaborates HRM. Functional elaboration should not be a "black box" to researchers and practitioners lest all we are left with is the sense that small-firm HRM is less sophisticated and professionalized than large-firm HRM, and that small size and fewer resources must surely be why. Such thinking does not fully explain why the small firm's owner-manager does or does not take the time and effort to think about the firm's HRM, decide how it needs to change, budget for and authorize what resources are needed for it, discuss HRM with affected employees and advisors, and so forth.

Can a small firm have ample financial resources and yet have an HRM function that is badly underfit relative to the firm's needs and contingencies? Yes. HRM's qualitative functional elaboration in the small firm may or may not be sufficient, and it behooves us to know what firm features besides just financial resources may influence especially low functional elaboration. Likewise, owner-manager motivation and ability to engage in the elaborative process certainly matter, so we also should identify those personal factors that, both alone and in conjunction with firm factors, shape that key decision-maker's actions and direct his or her attention. What many entrepreneurs may find is that some of these antecedent factors are certainly manageable to the end of enabling the degree of functional elaboration needed to ensure the small firm's HRM is keeping pace with contingent forces and is promoting firm performance rather than impeding it.

Wilkerson and Seers (2019) recommended that entrepreneurship education include a sober orientation to the risks of HRM's underfit with contingencies and education in skills, some "soft" skills and some analytical, the entrepreneur uses when actively elaborating the HRM function. We would extend that recommendation to teaching entrepreneurship students about the antecedents to functional elaboration and why so many small-firm owner-managers do not do it well enough when it comes to HRM. The entrepreneurship student should be made aware that the antecedents of qualitative and quantitative functional elaboration of the startup/early-stage firm's HRM are more than just resources and size. Since some of the relevant antecedents reside in the entrepreneur's motivations and abilities, students who aspire to entrepreneurship must also know that their own self-awareness and honest self-assessment of abilities are important (Lans, Biemans, Mulder, \& Verstegen, 2010). When they start their small firms, they should go into their ventures cognizant of their own HRM knowledge, attitudes toward HRM, and likelihood of seeking help from their networks and employees should risks of underfit arise due to their own failure to pay attention to and elaborate HRM. Equally important would be for entrepreneurship students and nascent entrepreneurs to receive feedback about elaboration-relevant strengths they do have, such that their self-awareness sharpens and possibly their entrepreneurial self-efficacy grows (Lans et al., 2010) as their small firms grow. 


\section{ACKNOWLEDGEMENT}

An earlier version of this work was presented at the 2020 annual conference of the United States Association for Small Business and Entrepreneurship in New Orleans, Louisiana.

\section{REFERENCES}

Ajzen, I. (1991). The theory of planned behavior. Organizational Behavior and Human Decision Processes, 50, 179-211.

Bacon, N., Ackers, P., Storey, J., \& Coates, D. (1996). It's a small world: Managing human resources in small businesses. International Journal of Human Resource Management, 7(1), 82-100.

Bacon, N., \& Hoque, K. (2005). HRM in the SME sector: Valuable employees and coercive networks. International Journal of Human Resource Management, 16, 1976-1999.

Barber, A. E. (2006). The hiring challenge: Recruitment in small firms. In J. W. Tansky \& R. L. Heneman (Eds.), Human resource strategies for the high growth entrepreneurial firm (pp. 99-113). Greenwich, CT: Information Age Publishing.

Barnett, T., \& Kellermanns, F. W. (2006). Are we family and are we treated as family? Nonfamily employees' perceptions of justice in the family firm. Entrepreneurship Theory and Practice, 30, 837-854.

Barney, J. (1991). Firm resources and sustained competitive advantage. Journal of Management, 17(1), 99-120.

Baron, J. N., Burton, M. D., \& Hannan, M. T. (1996). The road taken: Origins and evolution of employment systems in emerging companies. Industrial and Corporate Change, 5(2), 239-275.

Baron, R. A. (2006). Opportunity recognition as pattern recognition: How entrepreneurs "connect the dots" to identify new business opportunities. Academy of Management Perspectives, 20(1), 104119.

Barrett, R., \& Mayson, S. (2007). Human resource management in growing small firms. Journal of Small Business and Enterprise Development, 14(2), 307-320.

Bartram, T. (2005). Small firms, big ideas: The adoption of human resource management in Australian small firms. Asia Pacific Journal of Human Resources, 43(1), 137-154.

Bird, B. (1988). Implementing entrepreneurial ideas: The case for intention. Academy of Management Review, 13, 442-453.

Blackburn, R., \& Hart, M. (2002). Small firms' awareness and knowledge of individual employment rights. Surrey, England: Small Business Research Centre, Kingston University.

Brettel, M., Engelen, A., \& Voll, L. (2010). Letting go to grow-Empirical findings on a hearsay. Journal of Small Business Management, 48(4), 552-579.

Burns, T., \& Stalker, G. M. (1961). The management of innovation. London: Tavistock.

Cardon, M. S., \& Stevens, C. E. (2004). Managing human resources in small organizations: What do we know? Human Resource Management Review, 14(3), 295-323.

Cardy, R. L., \& Miller, J. S. (2006). Performance management in small and high growth companies. In J. W. Tansky \& R. L. Heneman (Eds.), Human resource strategies for the high growth entrepreneurial firm (pp. 115-133). Greenwich, CT: Information Age Publishing.

Chadwick, C., Way, S. A., Kerr, G., \& Thacker, J. W. (2013). Boundary conditions of the highinvestment human resource systems - small-firm labor productivity relationship. Personnel Psychology, 66, 311-343.

Chrisman, J. J., Memili, E., \& Misra, K. (2014). Nonfamily managers, family firms, and the winner's curse: The influence of noneconomic goals and bounded rationality. Entrepreneurship Theory and Practice, 38, 1103-1127.

Crain, N. V., \& Crain, W. M. (2010). The impact of regulatory costs on small firms. Washington, D.C.: U.S. Small Business Administration, Office of Advocacy. 
Davidsson, P. (1989). Entrepreneurship — and after? A study of growth willingness in small firms. Journal of Business Venturing, 4, 211-226.

Davila, T. (2005). An exploratory study on the emergence of management control systems: Formalizing human resources in small growing firms. Accounting, Organizations and Society, 30, 223-248.

De Kok, J. M. P., Uhlaner, L. M., \& Thurik, A. R. (2006). Professional HRM practices in family ownedmanaged enterprises. Journal of Small Business Management, 44(3), 441-460.

Fuller-Love, N. (2006). Management development in small firms. International Journal of Management Reviews, 8(3), 175-190.

Giddens, A. (1984). The constitution of society: Outline of the theory of structuration. Berkeley, CA: University of California Press.

Gorgievski, M. J., Ascalon, M. E., \& Stephan, U. (2011). Small business owners' success criteria, a values approach to personal differences. Journal of Small Business Management, 49(2), 207-232.

Goswami, R. M., McMahan, G. C., \& Wright, P. M. (2006). Toward an understanding of strategic human resource management in entrepreneurial firms: Opportunities for research and action. In J. W.

Tansky \& R. L. Heneman (Eds.), Human resource strategies for the high growth entrepreneurial firm (pp. 13-50). Greenwich, CT: Information Age Publishing.

Greer, C. R., Carr, J. C., \& Hipp, L. (2016). Strategic staffing and small-firm performance. Human Resource Management, 55(4), 741-764.

Hannan, M. T., Burton, M. D., \& Baron, J. N. (1996). Inertia and change in the early years: Employment relations in young, high technology firms. Industrial and Corporate Change, 5(2), 503-536.

Harris, L. (2000). Employment regulation and owner-managers in small firms: Seeking support and guidance. Journal of Small Business and Enterprise Development, 7(4), 352-362.

Harris, S. G. (1994). Organizational culture and individual sensemaking: A schema-based perspective. Organization Science, 5(3), 309-321.

Hayton, J. C. (2003). Strategic human capital management in SMEs: An empirical study of entrepreneurial performance. Human Resource Management, 42, 375-391.

Heneman, R. L., Tansky, J. W., \& Camp, S. M. (2000). Human resource management practices in small and medium-sized enterprises: Unanswered questions and future research perspectives. Entrepreneurship Theory and Practice, 25(1), 11-26.

Hoang, H., \& Antoncic, B. (2003). Network-based research in entrepreneurship: A critical review. Journal of Business Venturing, 18, 165-187.

Hornsby, J. S., \& Kuratko, D. F. (2003). Human resource management in U.S. small businesses: A replication and extension. Journal of Developmental Entrepreneurship, 8(1), 73-92.

Jay, L., \& Schaper, M. (2003). Which advisers do micro-firms use? Some Australian evidence. Journal of Small Business and Enterprise Development, 10(2), 136-143.

Katz, D., \& Kahn, R. L. (1978). The social psychology of organizations (2nd ed.). New York: Wiley.

Keating, M. A., \& Olivares, M. (2007). Human resource management practices in Irish high-tech start-up firms. Irish Journal of Management, 28(2), 171-192.

Klaas, B. S., \& Klimchak, M. (2006). Entrepreneurship and human resources: Directions for future research. In J. W. Tansky \& R. L. Heneman (Eds.), Human resource strategies for the high growth entrepreneurial firm (pp. 245-258). Greenwich, CT: Information Age Publishing.

Klaas, B. S., McClendon, J., \& Gainey, T. W. (2000). Managing HR in the small and medium enterprise: The impact of professional employer organizations. Entrepreneurship Theory and Practice, 25(1), 107-124.

Klaas, P., \& Donaldson, L. (2009). Underfits versus overfits in the contingency theory of organizational design: Asymmetric effects of misfits on performance. In A. Bøllingtoft, D. D. Håkonsson, J. F. Nielsen, C. C. Snow, \& J. Ulhøi (Eds.), New approaches to organizational design: Theory and practice of adaptive enterprises (pp. 147-168). New York, NY: Springer.

Klaas, P., Lauridsen, J., \& Håkonsson, D. D. (2006). New developments in contingency fit theory. In R. M. Burton, B. Eriksen, D. D. Håkonsson, \& C. C. Snow (Eds.), Organization design: The evolving state-of-the-art (pp. 143-164). New York, NY: Springer.

34 Journal of Organizational Psychology Vol. 20(1) 2020 
Koch, C. L. Y., \& de Kok, J. M. P. (1999). A human-resource-based theory of the small firm. EIM Research Report 9906/E. EIM Small Business Research and Consultancy: Zoetermeer, Netherlands.

Kotey, B., \& Meredith, G. G. (1997). Relationships among owner/manager personal values, business strategies, and enterprise performance. Journal of Small Business Management, 35(2), 37-64.

Kotey, B., \& Sheridan, A. (2004). Changing HRM practices with firm growth. Journal of Small Business and Enterprise Development, 11(4), 474-485.

Kotey, B., \& Slade, P. (2005). Formal human resource management practices in small growing firms. Journal of Small Business Management, 43(1), 16-40.

Lans, T., Biemans, H., Mulder, M., \& Verstegen, J. (2010). Self-awareness of mastery and improvability of entrepreneurial competence in small business in the agrifood sector. Human Resource Development Quarterly, 21(2), 147-168. doi: 10.1002/hrdq.20041

Leung, A., Zhang, J., Wong, P. K., \& Foo, M. D. (2006). The use of networks in human resource acquisition for entrepreneurial firms: Multiple "fit" considerations. Journal of Business Venturing, 21, 664-686.

Litz, R. A., \& Stewart, A. C. (2000). Research note: Trade name franchise membership as a human resource management strategy: Does buying group training deliver 'true value' for small retailers? Entrepreneurship Theory and Practice, 25(1), 125-135.

López, A., Neves, P., \& Cunha, M. (2019). A high-growth firm contingency test of the formalizationperformance relationship. Journal of Small Business Management, 57(S2), 374-396. doi: $10.1111 /$ jsbm. 12480

Marlow, S. (2002). Regulating labour management in small firms. Human Resource Management Journal, 12(3), 25-43.

Marlow, S. (2006). Human resource management in smaller firms: A contradiction in terms? Human Resource Management Review, 16(4), 467-477.

Marlow, S., Taylor, S., \& Thompson, A. (2010). Informality and formality in medium-sized companies: Contestation and synchronization. British Journal of Management, 21, 954-966.

Mayson, S., \& Barrett, R. (2006a). Human resource management in small firms: Evidence from growing small firms in Australia. In J. W. Tansky \& R. L. Heneman (Eds.), Human resource strategies for the high growth entrepreneurial firm (pp. 223-243). Greenwich, CT: Information Age Publishing.

Mayson, S., \& Barrett, R. (2006b). The 'science' and 'practice' of HRM in small firms. Human Resource Management Review, 16(4), 447-455.

Mazzarol, T. (2003). A model of small business HR growth management. International Journal of Entrepreneurial Behavior \& Research, 9(1), 27-49.

McKelvie, A., \& Wiklund, J. (2010). Advancing firm growth research: A focus on growth mode instead of growth rate. Entrepreneurship Theory and Practice, 34(2), 261-288.

Mintzberg, H. (1980). Structure in 5's: A synthesis of the research on organization design. Management Science, 26(3), 322-341.

Nankervis, A., Compton, R., \& Savery, L. (2002). Strategic HRM in small and medium enterprises: A CEO's perspective? Asia Pacific Journal of Human Resources, 40(2), 260-273.

Neck, H. M., \& Greene, P. G. (2011). Entrepreneurship education: Known worlds and new frontiers. Journal of Small Business Management, 49(1), 55-70.

Neckebrouck, J., Schulze, W., \& Zellweger, T. (2018). Are family firms good employers? Academy of Management Journal, 61, 553-585.

Oakey, R. P. (2003). Technical entrepreneurship in high technology small firms: Some observations on the implications for management. Technovation, 23, 679-688.

Patel, P. C., \& Cardon, M. S. (2010). Adopting HRM practices and their effectiveness in small firms facing product-market competition. Human Resource Management, 49(2), 265-290.

Perry, S. C. (2001). The relationship between written business plans and the failure of small businesses in the U.S. Journal of Small Business Management, 39(3), 201-208. 
Pollack, J. M., Rutherford, M. W., Seers, A., Coy, A. E., \& Hanson, S. (2016). Exploring entrepreneurs' social network ties: Quantity versus quality. Journal of Business Venturing Insights, 6, 28-35.

Rosenberg, M. J., \& Hovland, C. I. (1960). Cognitive, affective, and behavioral components of attitudes. In C. I. Hovland \& M. J. Rosenberg (Eds.), Attitude organization and change: An analysis of consistency among attitude components (pp. 1-14). New Haven, CT: Yale University Press.

Scarborough, N. M. (2011). Essentials of entrepreneurship and small business management (6th ed.). Upper Saddle River, NJ: Pearson.

Schwartz, S. H. (1992). Universals in the content and structure of values: Theoretical advances and empirical tests in 20 countries. In M. P. Zanna (Ed.), Advances in experimental social psychology (Vol. 25; pp. 1-65). New York: Academic Press.

Sels, L., De Winne, S., Maes, J., Delmotte, J., Faems, D., \& Forrier, A. (2006). Unraveling the HRMperformance link: Value-creating and cost-increasing effects of small business HRM. Journal of Management Studies, 43(2), 319-342.

Shepherd, D. A., Williams, T. A., \& Patzelt, H. (2015). Thinking about entrepreneurial decision making: Review and research agenda. Journal of Management, 41, 11-46.

Suddaby, R. (2010). Editor's comments: Construct clarity in theories of management and organization. Academy of Management Review, 35, 346-357.

Sutton, R. I., \& Staw, B. M. (1995). What theory is not. Administrative Science Quarterly, 40, 371-384.

Taylor, S. (2006). Acquaintance, meritocracy and critical realism: Researching recruitment and selection processes in smaller and growth organizations. Human Resource Management Review, 16(4), 478-489.

Tocher, N., \& Rutherford, M. W. (2009). Perceived acute human resource management problems in small and medium firms: An empirical examination. Entrepreneurship Theory and Practice, 33(2), 455-479.

Vardaman, J. M., Allen, D. G., \& Rogers, B. L. (2018). We are friends but are we family? Organizational identification and nonfamily employee turnover. Entrepreneurship Theory and Practice, 42(2), 290-309. doi: 10.1177/1042258717749235

Wach, D., Stephan, U., \& Gorgievski, M. (2016). More than money: Developing an integrative multifactorial measure of entrepreneurial success. International Small Business Journal, 34(8), 10981121.

Way, S. A. (2002). High performance work systems and intermediate indicators of firm performance within the US small business sector. Journal of Management, 28, 765-785.

Welsh, J. A., \& White, J. F. (1981). A small business is not a little big business. Harvard Business Review, 59(4), 18-32.

Whetten, D. A. (1989). What constitutes a theoretical contribution? Academy of Management Review, 14(4), 490-495.

Wiesner, R., \& McDonald, J. (2001). Bleak house or bright prospect? Human resource management in Australian SMEs. Asia Pacific Journal of Human Resources, 39(2), 31-53.

Wilkerson, J. M., \& Bassani, A. D. (in press). A functional elaboration theory perspective on management accounting in small firms. Journal of Accounting and Finance, 20(1).

Wilkerson, J. M., \& Seers, A. (2019). Chronic underfit of the small firm's HRM function: When low functional elaboration interacts with contingencies. Journal of Organizational Psychology, 19(2), 161-176.

Wright, P. M., \& Gardner, T. M. (2003). The human resource-firm performance relationship: Methodological and theoretical challenges. In D. Holman, T. D. Wall, C. W. Clegg, P. Sparrow, $\&$ A. Howard (Eds.), The new workplace: A guide to the human impact of modern working practices (pp. 311-328). West Sussex, England: Wiley.

Wright, P. M., \& McMahan, G. C. (1992). Theoretical perspectives for strategic human resource management. Journal of Management, 18, 295-320. 